\title{
PRODUCTS OF CHEMICAL REACTIONS THAT OCCUR DURING HIGH-TEMPERATURE HEAT TREATMENT OF THE MEAT PRODUCTS
}

Dmitry A. Utyanov, ${ }^{\star}$ Nataliya L. Vostrikova, Andrey V. Kulikovskii, Oksana A. Kuznetsova

V. M. Gorbatov's Federal Research Center for Food Systems of Russian Academy of Sciences, Moscow, Russia

Key words heterocyclic aromatic amines, carcinogens, meat products

\begin{abstract}
Recently the activety active studies have begun devoted to the accumulation of "harmful» substances in food products, which are supposedly accumulated in the body of a person who often consumes these products. Meat, as a source of full-featured animal protein, is especially popular in this aspect. For the preparation of meat products various types of heat treatment are used, almost each of which will inevitably lead to the destruction of some of the chemical compounds originally present in the product, and the formation of completely new chemical compounds, which can often be harmful to the human body. During high-temperature heat treatment (mainly frying), some chemical reactions in meat products occur, which lead to the formation of heterocyclic aromatic amines (HAA) in it. Due to the great variety of raw meat and cooking recipes, during the heat treatment HAA's of various classes are formed, each of them will be peculiar for the particular type of raw material or recipe components (with the exception of MeIQx and PhIP, which always form during frying). The more complete understanding of the HAA's formation mechanism will help study the products of Maillard reactions and Strecker degradation. In this work we studied the formation of HAA's as a result of the cyclization of creatine and the detaching of water (dehydration) from it during temperature exposure. The classification of the compounds formed as a result of these reactions is presented and the main classes of the HAA obtained in result are considered. The questions of the influence of various factors on amount of HAA formed, such as the fat content, the introduction of $\mathrm{Fe}^{2+}, \mathrm{Fe}^{3+}$, are raised. In the future it is necessary to conduct studies of the quantitative content of HAA in meat products to complement the already actively ongoing work on the study of xenobiotics consumed by humans with food, which will give a more comprehensive picture of the carcinogens content in food products.
\end{abstract}

\section{Introduction}

The modern outlook of the customer is formed currently by the mass media, the majority of «near-scientific (pseudoscientific)» data - are the European researches based on data extracted from various statistical publications (meta-data), that associate meat products with «oncology» risks. The International Agency Research on Cancer (IARC) released the monograph of meta-analysis performed in 2015, which results showed, that meat products have carcinogenic properties in certain conditions, which are explained by a wide range of xenobiotics trapped in the product from outside sources and directly formed in it during the heat treatment $[1,2]$.

Besides this, the National Cancer Institute informed, that during the heat treatment of food products with high protein content (meat, poultry, fish), it is produced the heterocyclic amino acids (HAA) - these substances are known of for their expressed carcinogenic and mutagenic properties $[3,4]$, which explains the need of conducting research of the chemical nature of their formation. Their mutagenic and carcinogenic properties have been proven both by the Ames test, and by the course of long-term experiments on the rodents and monkeys [5].

\section{Main part}

Based on the results [6] it can be concluded, that the main factors, contributing to the formation of the HAA in the product are the temperature $\left(150^{\circ} \mathrm{C}\right)$ and the duration of heat treatment, and also the contact of the product and the heating surface. Regarding this, the HAA will mainly be formed in products cooked at home, and also in public catering enterprises. The range of the HAA values content in food products varies from $1 \mu \mathrm{g} / \mathrm{kg}$ to $100 \mu \mathrm{g} / \mathrm{kg}$. The quantitative content of the HAA in food products is directly proportional to the temperature of heat treatment. The profile of the substances related to the HAA depends on the temperature in the same way $[7,8,9,10,11,12,13,14$, $15,16,17,18,19]$.

Raw materials and product recipe formulation, including to secondary factors, influence the quantitative content of the HAA in the meat products.

Firstly, the HAA were discovered in 1977 by the professor Takashi Sigimura and his collaborators, as a result of conventional home cooking processes. The beginning of the work on the HAA study was put by suspicions that the smoke, which is formed during the heat treatment of meat products, can be carcinogenic. Due to this there were discovered 20 different compounds, not registered as recipe components, which are actually formed during heat treatment, and they fell into the category of the HAA $[7,9]$.

In the 80 s of the last century, on the basis of the assumption on formation of mutagenic HAA groups of imidazoquinolines and imidazoquinoxalines during the Maillard reaction, a mechanism for the formation of the HAA was proposed [19] (Figure 1). 


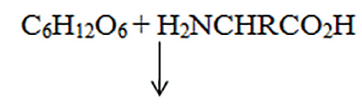

Maillard Degradation reaction by Strecker
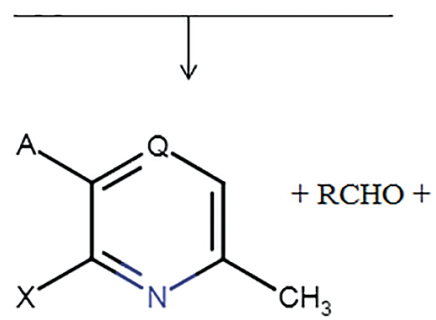

$\mathrm{Q}=\mathrm{CH}, \mathrm{N}$<smiles>CN(CC(=O)O)C(=N)N</smiles><smiles>CN(CC(=O)O)C(=N)NP(=O)(O)O</smiles>

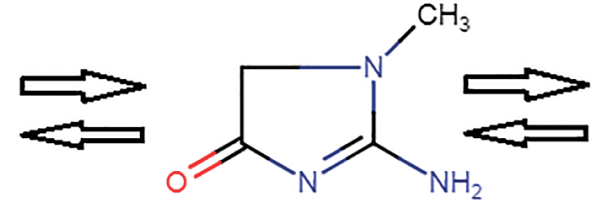

Creatinine

\begin{tabular}{|l|l|l|l|l|}
\hline Designations & X & A & Q & R \\
\hline IQ & $\mathrm{H}$ & $\mathrm{H}$ & $\mathrm{CH}$ & $\mathrm{H}$ \\
\hline MeIQ & $\mathrm{H}$ & $\mathrm{H}$ & $\mathrm{CH}$ & $\mathrm{Me}$ \\
\hline MqIQx & $\mathrm{H}$ & $\mathrm{Me}$ & $\mathrm{N}$ & $\mathrm{H}$ \\
\hline 7,8-DiMeIQx & $\mathrm{Me}$ & $\mathrm{Me}$ & $\mathrm{N}$ & $\mathrm{H}$ \\
\hline 4,8-DiMeIQx & $\mathrm{H}$ & $\mathrm{Me}$ & $\mathrm{N}$ & $\mathrm{Me}$ \\
\hline
\end{tabular}

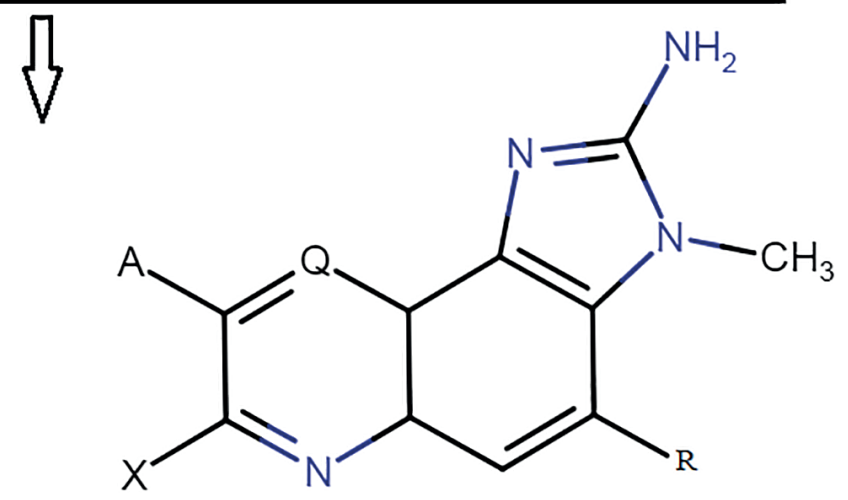

Figure 1. Mechanism of formation of HAA

In result of cyclization and detaching of water, according to the proposed scheme, creatine turns into creatinine and form forms the amino-imidazole part of the HAA, and the Strecker degradation products, such as pyridine derivatives or pyrazines, formed in result of the Maillard reaction between hexoses and free amino-acids, «completing» the chemical structure of the HAA. The important participant in the "completion» of the HAA molecule is the so-called Strecker aldehyde (or the corresponding base of Schiff), which is also formed in result of Strecker degradation.

As we can see from the name, the HAA have at least one heterocyclic ring and the amino group. Heterocyclic ring is a cyclic hydrocarbon, in which one or more carbon atoms are replaced by other atoms (with oxygen heteroatom). In most cases the heteroatom is nitrogen and less often it is oxygen, and still less often it is sulfur. In cases, where the heteroatom is nitrogen, the compound is an amine itself, in other cases the aminogroup is attached to the heterocycle. The majority of the HAA, except the group of $\beta$-carbolines (such as harman and norharman, Figure 2 and 3 respectively), the aminogroup is located out of the cycles.

The natural content of the HAA can be found, ranging from plants and algae to vitamins and antibiotics.<smiles>Cc1nccc2c1[nH]c1ccccc12</smiles>

Figure 2. Harman (1-methyl-9H-pyrido[3,4-b]indole)
The HAA, which are formed in result of heat treatment of high-protein foods, being the carcinogens, can be divided into two major groups.

The first group includes aminoimidazoarenes (AIA) or «thermal» HAA, which have in their molecule N-methyl-2-aminoimidazole part. These HAA are usually formed during the «home» cooking temperatures of $150{ }^{\circ} \mathrm{C}$ primarily as a result of the reaction of aminoacids pyrolysis products (such as pyridine and pyrizine) with creatine and carbohydrates, forming imidazoquinolines (IQ), imidazoquinoxalines (IQx), and imidazopyridines (Fig. 4) [10,18,19].

Figure 5 shows the presumed reaction of IQ and IQx formation. Depending on the polarity, aminoimidazoarenas can be divided to polar and nonpolar.

The second group — «the pyrolytic HAA» or aminocarbolins are formed by higher temperatures (over $300^{\circ} \mathrm{C}$ ) by thermal destruction of tryptophan, phenylalanine, ornithine and glutamic acid. At high temperatures, these amino acids form desaminated and decarboxylic reaction products with reactive radical fragments, the condensation of which produces heterocyclic ring structures. This group mainly includes one of the fragments of 5 structurally different groups of pyridoindole, pyridoimidazole, phenylpyridine, tetraazaflurantene or benzimidazole (Figure 6) [11,12,19].

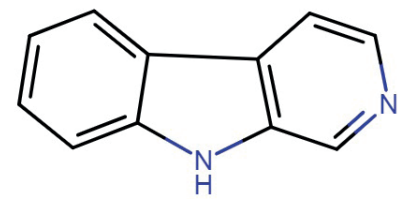

Figure 3. Norharman (9H-pyrido[3,4-b]indole) 


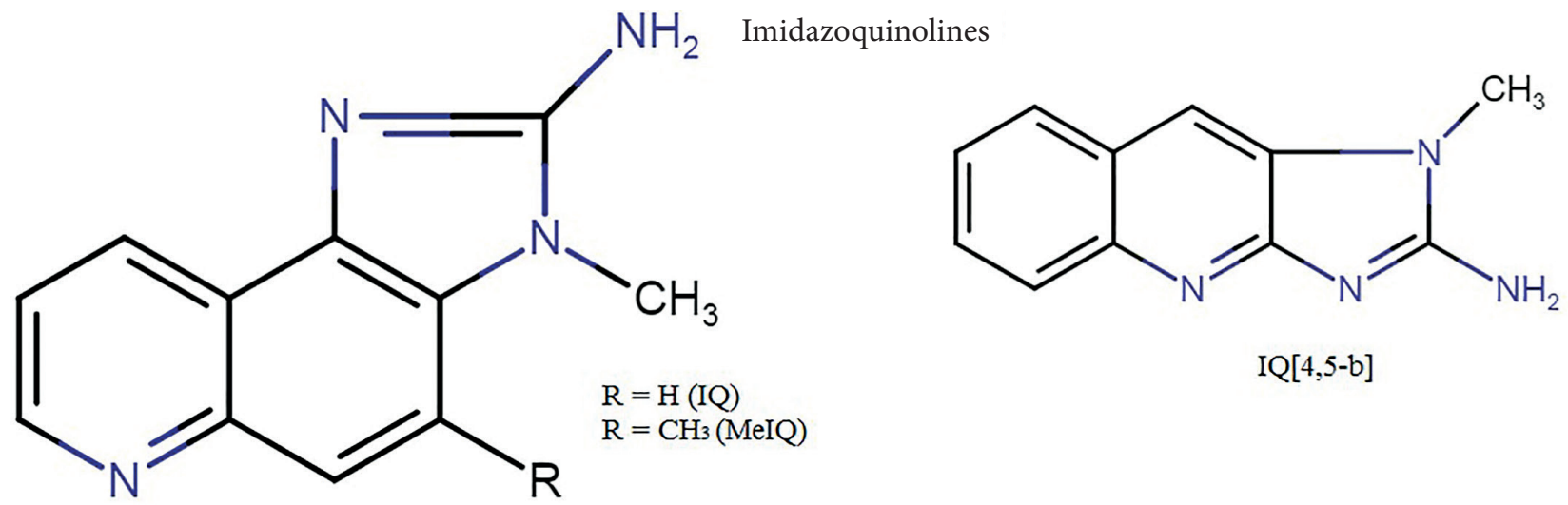

Imidazoquinoxalines<smiles>[R2]c1nc2cc([R1])c3c(nc(N)n3C)c2nc1[R3]</smiles>

$\mathrm{R} 1, \mathrm{R} 2, \mathrm{R} 3=\mathrm{H}$ (IQx)

$\mathrm{R} 1, \mathrm{R} 2=\mathrm{H}, \mathrm{R} 3=\mathrm{CH}_{3}$ (8-MeIQx)

$\mathrm{R} 1=\mathrm{CH}_{3}, \mathrm{R} 2, \mathrm{R} 3=\mathrm{H}(4-\mathrm{MeIQx})$

$\mathrm{R} 1, \mathrm{R} 3=\mathrm{CH} 3, \mathrm{R} 2=\mathrm{H}(4,8$-DiMeIQx $)$

$\mathrm{R} 1, \mathrm{R} 2=\mathrm{CH}_{3}, \mathrm{R} 3=\mathrm{H}(7,8$-DiMeIQx)

$\mathrm{R} 1, \mathrm{R} 2, \mathrm{R} 3=\mathrm{CH}_{3}(4,7,8$-TriMeIQx)

$\mathrm{R} 1=\mathrm{CH}_{2} \mathrm{OH}, \mathrm{R} 2=\mathrm{H}, \mathrm{R} 3=\mathrm{CH}_{3}(4-\mathrm{CH} 2 \mathrm{OH}-8-\mathrm{MeIQx})$<smiles>[R2]c1nc2cc3nc(N)n(C)c3c([R3])c2nc1[R2]</smiles>

$\mathrm{R} 1, \mathrm{R} 2, \mathrm{R} 3=\mathrm{H}(\operatorname{IgQx})$

$\mathrm{R} 1, \mathrm{R} 3=\mathrm{H}, \mathrm{R} 2=\mathrm{CH}_{3}(7-\mathrm{MeIgQx})$

$\mathrm{R} 1, \mathrm{R} 2=\mathrm{CH}_{3}, \mathrm{R} 3=\mathrm{H}(6,7$-DiMeIgQx $)$

$\mathrm{R} 1=\mathrm{H}, \mathrm{R} 2, \mathrm{R} 3=\mathrm{CH}_{3}(7,9-\mathrm{DiMeIgQx})$<smiles>[R]c1ccc(-c2cnc3nc(N)n(C)c3c2)cc1</smiles><smiles>[R7]c1cc2c(nc1[R7])NC(N)N2C</smiles>

$\mathrm{R} 1=\mathrm{H}, \mathrm{R} 2=\mathrm{CH} 3(1,6-\mathrm{DMIP})$ $\mathrm{R} 1, \mathrm{R} 2=\mathrm{CH} 3(1,5,6-\mathrm{TMIP})$

$\mathrm{R}=\mathrm{H}$ (PhIP)

$\mathrm{R}=\mathrm{OH}(4-\mathrm{OH}-\mathrm{PhIP})$

Figure 4. Graphic formulas of imidazoquinolines, imidazoquinoxalines and pyridines<smiles>[R]C=CC(C)(C)c1cc(C)nc([X])c1O</smiles>

If $\mathrm{A}=\mathrm{CH}-$ Pyridine If $\mathrm{A}=\mathrm{N}-$ Pyrazine

Figure 5. The presumed reaction of IQ and IQx formation<smiles>CN1CC(=O)N=C1N</smiles>

Creatinine<smiles>[R]c1nc2cc([X])c3[nH]c(N)nc3c2cc1O</smiles>

Derivative IQ or IQx 


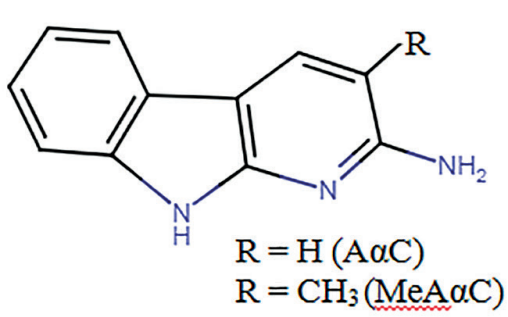

Alpha-carboline

\section{Pyridoindoles}

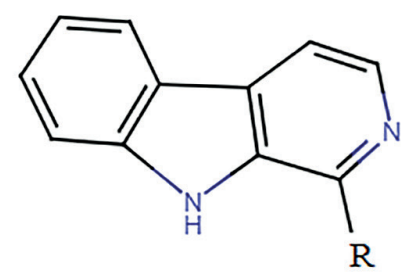

$\mathrm{R}=\mathrm{H}$ (Norharman)

$\mathrm{R}=\mathrm{CH}_{3}$ (Harman)

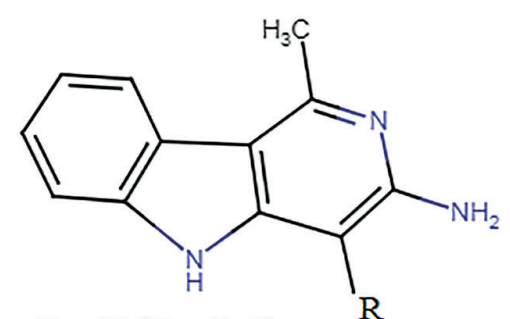

$\mathrm{R}=\mathrm{H}(\mathrm{Trp}-\mathrm{P}-1)$

$\mathrm{R}=\mathrm{CH}_{3}(\operatorname{Trp}-\mathrm{P}-2)$

Gamma-carboline

Beta-carboline

Pyridomidazoles

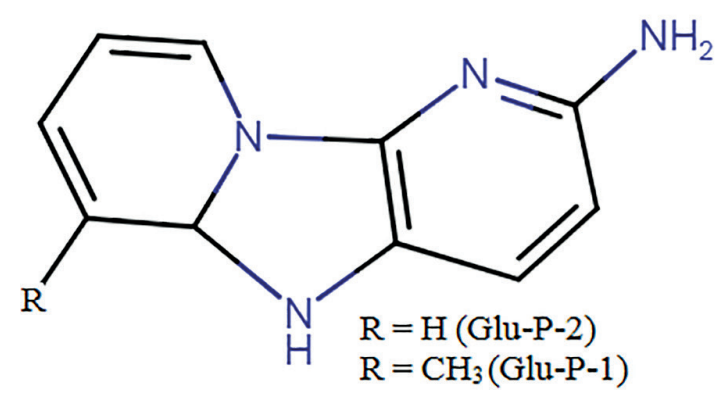

Tetrafluoroethan

Figure 6. Graphic formulas of 2 groups of the HAA

Due to the fact that AIA are formed at lower temperatures, they are more common and, accordingly, are mutagenic and carcinogenic HAA studied in a better way. Also, alpha- and gamma-carbolines are mainly formed as a result of pyrolysis of plant proteins in concentrations 10-100 times less than the number of the formed beta-carbolines, such as harman and norharman [18].

In 1993 the IARC considered 8 Heterocyclic aromatic amines (HAA), (MeIQ, 8-MeIQx, PhIP, AaC, MeAaC, Trp-P-1, Trp-P-2 and Glu-P-1) as possible carcinogens for humans (class 2B) and 1 (IQ) as probable carcinogen for humans (class $2 \mathrm{~A}$ ) and recommended reducing exposure to these compounds. So in 2004, IQ, MeIQ, 8-MeIQx and PhIP were listed in the National toxicology program, because they are carcinogenic to humans [20]. These results are based on the results of long-term animal experiments. Although the epidemiological evidence suggests that the roasted meat consumption is associated with an increased risk of cancer in humans, data were insufficient to confirm
Phenylpyridine

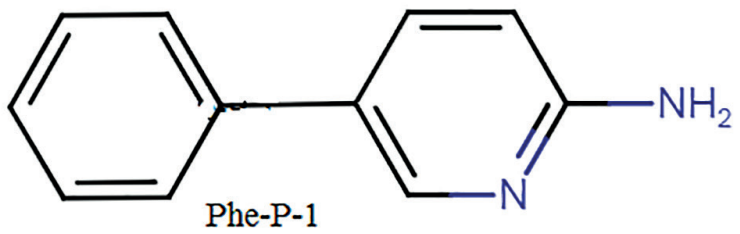

Benzimidazole<smiles>CNc1nc2cc3c(cc2n1C)C(=O)N(C)C3=O</smiles>

that this risk is caused due to the presence of the HAA (MeIQ, 8-MeIQx, or PhIP). Sample studies show very contradictory results.

The HAA, a family of mutagenic compounds, are formed during the cooking process of many animal products, including chicken, beef, pork, and fish. Meat, cooked with moderate temperatures but grilled or fried, can contain significant amounts of these mutagens. [8,19].

The longer the meat is cooked and the higher is the temperature, the more these compounds are formed $[6,7,8,9,10]$. Studies have shown that during the cooking of the grilled chicken the higher concentration of the HAA were found than in other types of meat [19].

The main classes of heterocyclic amines include aminoimidazoquinolines or aminoimidazoquinoxalines (collectively called type IQ compounds) and aminoimidazopyridines such as PhIP. Compounds such as IQ and PhIP are formed from creatine or creatinine, specific amino acids and sugars [13]. All meat (including fish) contains a large 
amount of creatine, because of what the maximum formation of the HAA occurs during the cooking of meat at high temperatures (grilled or fried). Eating deep-fried meat and $\mathrm{PhIP}$ is associated with an increased risk of breast cancer and colon cancer $[20,21,22,23,24,25,26,27]$.

In addition to the type and duration of heat treatment, the amount of the HAA produced is influenced by the content of antioxidants, precursors, and the HAA inhibitors in the product. One of the inhibitors, but at the same time a catalyst in the reaction of the HAA formation in the product is fat. In research [6] the experiment was carried out, where the semi-finished meat products with different mass fraction of fat were subjected to frying. The results showed that with a relatively low fat content in the product (no more than $20 \%$ ), the amount of the formed HAA grew in direct proportion to the amount of fat, and with an amount of fat over $20 \%$, the amount formed during heat treatment of the HAA was less in comparison with the samples where the fat content was less than $20 \%$, but at the same time it remained relatively stable and did not change with further changes in the amount of fat in the recipe formulations of the products. Most likely, this is due to the fact that a large amount of fat in the product acts as a wall between the product and the heating surface, and with smaller amounts of fat this fat is involved in the reaction to form the HAA. An important role is played by the type of the fats used - the greatest mutagenic activity was found while using butter, and the use of vegetable oils leads to the formation of smaller amounts of food mutagens. It was found that the introduction of iron $(\mathrm{Fe} 2+, \mathrm{Fe} 3+)$ increases the number of formed IQ and IQx almost in two times. The amount of moisture in the recipe formulation components also influences the concentration of the HAA, possibly because of its role as a transporter of water-soluble HAA precursors.

\section{Conclusion}

Currently there is a need for experimental studies of the HAA content in food products, which will be another block of great work on the study of xenobiotics entering the human body with food products, which will complement the picture of the chemical carcinogens content in the food products.

In world practice the meat products are considered as high-risk products, which are characterized by both biological and chemical risks. The Codex Alimentarius and the World Organisation for Animal Health (OIE) documents provide guidance on the application of a risk-based approach to the analysis of products of animal origin. However, in Codex Alimentarius they refer to the finished product and are considered in relation to a human health, and in OIE documents they refer mostly to the veterinary welfare of farm animals. The technological component is not highlighted in these documents, but it serves as an essential mechanism for managing both individual risks and their aggregate combination, which allows producing a product of guaranteed safety during its shelf life.

In many ways the harm from red meat is determined not so much by the properties of the meat, as by the methods of its cooking and combination with other foods. Often the product becomes harmful because of ignorance of elementary rules of its use. In general, this review emphasizes that species differences and data on the mechanisms of toxic action must be taken into account when transferring data on carcinogenic risks obtained from the use of large doses of the tested substance in experimental animals, to humans receiving small doses of this substance.

The primary objective of the study of the HAA accumulation is to select an indicator of the presence of carcinogens of this type. A range of researchers have found that the most common HAA are PhIP (2-amino-1-methyl-6phenylimidazo[4,5 b]pyridine) and MeIQx (2-amino-3,8-dimethylimidazo[4,5 $\mathrm{f}$ ]quinoxaline) [8]. Therefore these substances were selected as the main markers for further monitoring of the quantitative content of the HAA in the food products, carried out within the framework of the State task on the basis of the laboratory of the Scientific and methodological works, biological and analytical researches of the V. M. Gorbatov's Federal Research Center for Food Systems.

\section{REFERENCES}

1. IARC Monographs evaluate consumption of red meat and processed meat. [Electronic resource: http://scienceblog.cancerresearchuk.org/2015/10/26/processed-meat-and-cancerwhat-you-need-to-know Access date 14.11.2019]

2. Carcinogenicity of consumption of red and processed meat. Published early online October 26, 2015 in The Lancet Oncology. First author Veronique Bouvard, International Agency for Research on Cancer Monograph Working Group, Lyon, France. [Electronic resource: https://www.cancer.org/latest-news/world-health-organizationsays-processed-meat-causes-cancer Access date 24.10.2019] 3. Vostrikova N. L., Kuznetsova O. A., Kulikovskii A. V., Minaev M. Y. (2017). Formation of the scientific basis of meta-data associated with estimates of "onco-" risks linked to meat products. Theory and practice of meat processing, 2(4), 96-113. DOI: 10.21323/2414-438X-2017-2-4-96-113 (In Russian)

4. Some Naturally Occurring Substances: Food Items and Constituents, Heterocyclic Aromatic Amines and Mycotoxins. (1993). IARC Monographs on the Evaluation of Carcinogenic Risks to Humans Volume 56. Lyon: World Health Organization. Intl. Agency for Research on Cancer. ISBN 978-92-832-1256-0
5. Ferlay, J., Soerjomataram, I., Dikshit, R., Eser, S., Mathers, C. Rebelo, M., Parkin, D.M., Forman, D., Bray, F. Cancer incidence and mortality worldwide: Sources, methods and major patterns in GLOBOCAN2012. International Journal of Cancer, 136, E359E386. DOI: 10.1002/ijc.29210

6. Solaykov, A.A. (1998). The influence of the thermal treatment and preparation methods of semifinished products for the content of heterocyclic aromatic amines in fried meat food products. Author's abstract of the thesis work applied for the scientific degree of Candidate of Technical Sciences. M: G. V. Plekhanov's Russian University of Economics. -27 p. (In Russian)

7. Gibis, M. (2007). Occurrence of carcinogenic heterocyclic aromatic amines in fried patties of different animal species. Proceedings of the 53th International Congress of Meat Science and Technology, Beijing, China, P. 13.

8. Puangsombat, K., Gadgil, P., Houser, T.A., Hunt, M.C., Smith, J.S. (2012). Occurrence of heterocyclic amines in cooked meat products. Meat Science, 90(3), 739-746. DOI: 10.1016/j.meatsci.2011.11.005 
9. Alaejos, M.S., Afonso, A.M. (2011). Factors that affect the content of heterocyclic aromatic amines in foods. Comprehensive reviews in food science and food safety, 10(2), 52-108. DOI: 10.1111/j.1541-4337.2010.00141.x

10. Buła, M., Przybylski, W., Jaworska, D., Kajak-Siemaszko, K. (2018). Formation of heterocyclic aromatic amines in relation to pork quality and heat treatment parameters. Food Chemistry, 276, 511-519. DOI: 10.1016/j.foodchem.2018.10.073

11. Jägerstad, M., Skog, K., Grivas, S., Olsson, K. (1991). Formation of heterocyclic amines using model systems. Mutation Research/Genetic Toxicology, 259(3-4), 219-233. DOI: 10.1016/0165-1218(91)90119-7

12. Messner, C., Murkovic, M. (2004). Formation of heterocyclic aromatic amines in model systems. Journal of Chromatography B: Analytical Technologies in the Biomedical and Life Sciences, 802(1), 3-10. DOI: 10.1016/j.jchromb.2003.09.026

13. Kataoka, H., Miyake, M., Saito, K., Mitani, K. Formation of heterocyclic amine-amino acid adducts by heating in a model system Food Chemistry,130(3), 725-729. DOI: 10.1016/j.foodchem.2011.07.094

14. Skog, K.I., Johansson, M.A.E., Jägerstad, M.I. (1998). Carcinogenic heterocyclic amines in model systems and cooked foods: a review on formation, occurrence, and intake. Food and Chemical Toxicology, 36, 879-896. DOl: 10.1016/s0278-6915(98)00061-1 15. Teng, H., Chen, Y., Lin, X., Lv, Q., Chai, T.-T., Wong, F.-C. Chen, L., Xiao, J.(2019). Inhibitory effect of the extract from Sonchus olearleu on the formation of carcinogenic heterocyclic aromatic amines during the pork cooking. Food and Chemical Toxicology,129, 138-143. DOI: 10.1016/j.fct.2019.04.043

16. Yang, D., He, Z., Gao, D., Qin, F., Deng, S., Wang, P., Xu, X., Chen, J., Zeng, M. (2019).Effects of smoking or baking procedures during sausage processing on the formation of heterocyclic amines measured using UPLC-MS/MS. Food Chemistry, 276, 195-201. DOI: 10.1016/j.foodchem.2018.09.160

17. Soladoye, O.P., Shand, P., Dugan, M.E.R., Gariépy, C., Aalhus, J.L., Estévez, M., Juárez, M. (2017). Influence of cooking methods and storage time on lipid and protein oxidation and heterocyclic aromatic amines production in bacon. Food Research International, 99, 660-669. DOI: 10.1016/j.foodres.2017.06.029

18. Sinha, R., Rothman, N., Salmon, C.P., Mark, S.D., Brown, E.D., Levander, O.A., Knize, M.G., Swanson, C. A. Felton, J.S., Rossi, S.C.
(1995). High Concentrations of the Carcinogen 2-Amino-1-methyl-6-phenylimidazo-[4,5-b]pyridine (PhIP) Occur in Chicken but Are Dependent on the Cooking Method. Cancer Research, 55(20), 4516-4519

19. Jägerstad, M., Reuterswärd, A.L., Olsson, R., Grivas, S., Nyhammar, T, Olsson, K., Dahlqvist, A. (1983). Creatin(in)e and Maillard reaction products as precursors of mutagenic compounds: Effects of various amino acids. Food Chemistry, 12(4), 255-264. DOI: 10.1016/0308-8146(83)90014-6

20. NTP Report on Carcinogens. Selected heterocyclic amines. U. S. Department of Health and Human Services. Public Health Service. Natl. Toxicology Program. Eleventh Edition, 2004, P.135. 21. Robbana-Barnat, S., Rabache, M., Rialland, E., Fradin, J. (1996). Heterocyclic amines: occurrence and prevention in cooked. Environmental Health Perspectives, 104(3), 280-288. DOI: 10.1289/ehp.96104280

22. Chan, D.S.M., Lau, R., Aune, D., Vieira, R., Greenwood, D.C., Kampman, E., Norat, N. (2011). Red and Processed Meat and Colorectal Cancer Incidence: Meta-Analysis of Prospective Studies. PLOS ONE, 6(6), e20456. DOI: 10.1371/journal. pone.0020456

23. Bruce, W.R. (1987). Recent hypotheses for the origin of colon cancer. Cancer Research, 47(16), 4237-4242.

24. Thiebaud, H.P., Knize, M.G., Kuzmicky, P.A., Hsieh, D. P. Felton, J.S. (1995). Airborne mutagens produced by frying beef, pork, and a soy-based food. Food and Chemical Toxicology, 33(10), 821-828. DOI: 10.1016/0278-6915(95)00057-9

25. Murtaugh, M.A., Ma, K.N., Sweeney, C., vCaan, B.J., Slattery, M.L. (2004). Meat Consumption patterns and preparation, genetic variants of metabolic enzymes, and their association with rectal cancer in men and women. The Journal of Nutrition, 134(4), 776-784. DOI: 10.1093/jn/134.4.776

26. García-Closas, R., García-Closas, M., Kogevinas, M., Malats, N., Silverman, D., Serra, C., et al. (2007). Food, nutrient and heterocyclic amine intake and the risk of bladder cancer. European Journal of Cancer, 43(11), 1731-1740. DOI: 10.1016/j. ejca.2007.05.007

27. Rahman, U.U., Sahar, A., Khan, M.I., Nadeem, M. (2014). Production of heterocyclic aromatic amines in meat: Chemistry, health risks and inhibition. A review. LWT - Food Science and Technology, 59(1), 229-233. DOI: 10.1016/j.Iwt.2014.06.005

\section{AUTHOR INFORMATION}

Dmitry A. Utyanov - scientific worker, Laboratory of scientifically-methodical works and control-analytical researches, V. M. Gorbatov Federal Research Center for Food Systems of Russian Academy of Sciences, 109316, Moscow, Talalikhina str., 26. Tel.: +7-495-676-79-61, E-mail: d.utyanov@fncps.ru

*corresponding author

Andrey V. Kulikovskii - candidate of technical sciences, a head chromatography laboratory, leading scientific worker of the Laboratory «Scientific and methodical work, biological and analytical research» V. M. Gorbatov Federal Research Center for Food Systems of Russian Academy of Sciences, 109316, Moscow, Talalikhina str., 26, Tel.: +-495-676-60-11, E-mail: a.kulikovskii@fncps.ru

Natal'ya L. Vostrikova - candidate of technical sciences, head of laboratory «Scientific and methodical work, biological and analytical research», V. M. Gorbatov Federal Research Center for Food Systems of Russian Academy of Sciences, 109316, Moscow, Talalikhina str., 26, Tel.: +7-495676-79-81, E-mail: n.vostrikova@fncps.ru

Oksana A. Kuznetsova - doctor of technical sciences, director, V. M. Gorbatov Federal Research Center for Food Systems of Russian Academy of Sciences,109316, Moscow, Talalikhina str., 26, Tel.: +7-495-676-72-11, E-mail: o.kuznecova@fncps.ru

All authors bear responsibility for the work and presented data.

All authors made an equal contribution to the work.

The authors were equally involved in writing the manuscript and bear the equal responsibility for plagiarism.

The authors declare no conflict of interest.

Received 09.09.2019 Accepted in revised 24.10.2019 Accepted for publication 15.12.2019 